CIVICS EDUCATION AND SOCIAL SCIENSE JOURNAL(CESSJ)

Volume 3 Nomor 1 Edisi Bulan Juni 2021

\title{
STRATEGI GURU PPKN DALAM MENGEMBANGKAN INSTRUMEN PENILAIAN KECAKAPAN KEWARGANEGARAAN
}

\author{
Ratih Nur Indah Sari1, Winarno ${ }^{2}$,Triana Rejekiningsih ${ }^{3}$ \\ PPKn FKIP Universitas Sebelas Maret, Surakarta \\ email : ratihnur98@student.uns.ac.id; winarnoarmoatmojo@staff.uns.ac.id; \\ triana_rizq@staff.uns.ac.id
}

\begin{abstract}
ABSTRAK
Penelitian ini bertujuan untuk mengetahui: 1) strategi guru PPKn dalam mengembangkan instrumen penilaian kecakapan kewarganegaraan; dan 2) kendala dan solusi dalam mengembangkan instrumen penilaian kecakapan kewarganegaraan. Metode yang digunakan kualitatif dengan pendekatan studi kasus. Pengumpulan data menggunakan wawancara, observasi, dan studi dokumen. Pengujian validitas data menggunakan model analisis triangulasi data dan triangulasi metode. Analisis data menggunakan model analisis spradly. Kecakapan kewarganegaraan terdiri dari kecakapan intelektual dan kecakapan partisipasi maka instrumen penilaian juga harus dapat mengukur kedua aspek tersebut. Hal ini karena penilaian PPKn merupakan gabungan dari pemahaman konsep serta penerapannya. Simpulan penelitian adalah guru dalam menilai kecakapan kewarganegaraan menggunakan bentuk penilaian kinerja, kemudian instrumen yang digunakan adalah lembar pengamatan kinerja. Strategi yang dijalankan yaitu: a) memperhatikan karakteristik siswa setiap kelas atau jurusan/program keahlian terkait pemahaman materi dan tingkat berpikir siswa saat pembelajaran; b) memperhatikan Kompetensi Dasar (KD) dan materi yang akan dibuat soal atau instrumen; c) menyusun kisi-kisi penilaian; d) menentukan teknik dan bentuk instrumen penilaian; e) mencari permasalahan/kasus yang dapat dikaitkan dengan materi pembelajaran, f) menyusun soal, kriteria (rubrik) penilaian dan pedoman penskroran; g) menelaah soal berdasarkan kaidah pembuatan soal dan kriteria instrumen penilaian psikomotor. Kendala yang dialami guru PPKn dalam mengembangkan instrumen penilaian kecakapan kewarganegaraan yaitu: a) kesulitan guru dalam menentukan permasalahan/kasus yang dikaitkan dengan materi untuk menjadi bahan diskusi atau presentasi; b) karakteristik siswa masih kurang dalam keaktifan dan penguasaan materi pembelajaran; c) kesulitan guru dalam menentukan aspek penilaian keterampilan siswa saat Pembelajaran Jarak Jauh (PJJ). Sedangkan solusi dari kendala dalam mengembangkan instrumen penilaian kecakapan kewarganegaraan yaitu: a) mengikuti berita yang terjadi di masyarakat serta kreatif dalam mengaitkan dengan materi; b) memberikan motivasi dan ajakan secara terus menerus kepada siswa; serta c) pengadaan workshop terkait peningkatan profesionalitas guru dalam Pembelajaran Jarak Jauh (PJJ).
\end{abstract}

Kata Kunci: Penilaian, Kecakapan, Kewarganegaraan, Intelektual, Partisipasi, Psikomotor

JORNAL PROGDI PPKn, FKIP UNIVET BANTARA SUKOHARJO BEKERJA SAMA DENGAN ASSOSIASI PROFESI PENDIDIKAN PANCASILA DAN KEWARGANEGARAAN (AP3KNI) JAWA TENGAH 
CIVICS EDUCATION AND SOCIAL SCIENSE JOURNAL(CESSJ)

Volume 3 Nomor 1 Edisi Bulan Juni 2021

\section{ABSTRACT}

This research aims to find out: 1)strategies Pancasila and civic Education teacher in developing instrument of civic skills assessment; and 2)problems and solutions in developing instrument of civic skills assessment.

In this study, the researcher uses qualitative method with case study approach. Data collection process involves interviews, observations, and document study. Data validity test uses analysis model of both data triangulation and method triangulation. Meanwhile data analysis applies Spradly analysis model. Civic skills consist of intellectual skills and participation skills, so the assessment instrument must also be able to measure these two aspects. This is because the Pancasila and Cicic Education assessment is a combination of understanding the concept and its application.

The conclusion of this study is that teachers in assessing civic skills use a form of performance appraisal, then the instrument used is the performance observation sheet.Therefore, the strategies used by Pancasila and Civic Education teacher in developing instruments of civic skills assessment, such as: a) observing the characteristics of students in every class of any expertise program related to material understanding and level of thinking among the students during the teaching learning process; b) considering competencies or Kompetensi Dasar (KD) and the learning materials for the test construction or instrument; c) compile the scoring grid; d) determining techniques and assessment instrument forms; e) finding out problem or case which can be linked to learning materials; f) constructing test items, assessment criteria (rubric) and scoring guideline; g) analyzing test items based on the principles of constructing test items and criteria of psychomotoric assessment instrument. Problems encountered by Pancasila and Civic Education teacher in this study in developing assessment instrument of civic skills are: a) teacher's difficulty in finding problems/case regarding learning materials for the topics of both discussion and presentation; b) students' characteristics such as low in both activeness and learning materials mastery; c) teacher's difficulty in determining aspects of student skill during Distance Learning. Meanwhile, solutions of the aforementioned problems in developing instruments of civic skill assessment are: a) being up-to-date about recent news circulating among the society and creative in linking them to the materials; b) giving continuous motivation and persuasion to the students; c) procurement of workshops related to improving teacher professionalism in Distance Learning.

Keywords: Assessment, Skills, Civic, Intellectual, Participatory, Psychomotor

JORNAL PROGDI PPKn, FKIP UNIVET BANTARA SUKOHARJO BEKERJA SAMA DENGAN ASSOSIASI PROFESI PENDIDIKAN PANCASILA DAN KEWARGANEGARAAN (AP3KNI) JAWA TENGAH 


\section{PENDAHULUAN}

Undang-Undang Nomor 20 Tahun 2003 Tentang Sistem Pendidikan Nasional Pasal 1 menyebutkan bahwa Pendidikan Nasional adalah usaha sadar dan terencana untuk mewujudkan suasana belajar dan proses pembelajaran agar peserta didik secara aktif mengembangkan potensi dirinya untuk memiliki kekuatan spiritual keagamaan, pengendalian diri, kepribadian, kecerdasan, akhlak mulia, serta keterampilan yang diperlukan dirinya, masyarakat bangsa dan negara. Upaya pemerintah dalam melaksanakan sistem pendidikan nasional sesuai UndangUndang Nomor 20 Tahun 2003 tersebut adalah ditetapkan Peraturan Pemerintah Nomor 19 Tahun 2005 Tentang Standar Nasional Pendidikan yaitu antara lain standar isi, standar proses, standar kompetensi lulusan, standar pendidik dan tenaga kependidikan, standar sarana dan prasarana, standar pengelolaan, standar pembiayaan dan standar penilaian pendidikan. Standar penilaian pendidikan merupakan standar yang sangat penting dalam perwujudan tujuan nasional pendidikan.

Di Indonesia standar penilaian pendidikan telah diatur dalam sebuah kurikulum pendidikan nasional, sehingga terjadi keseragaman baik dalam perencanaan, pelaksanaan ataupun penilaian (evaluasi) pembelajaran. Indonesia saat ini menerapkan kurikulum 2013 edisi revisi. Dalam kurikulum 2013 ini terdapat 4 (empat) perubahan dalam standar penilaiannya yaitu: a) penilaian berbasis kompetensi; b) pergeseran dari penilaian yang hanya mengukur kognitif atau pengetahuan berdasarkan hasil saja berubah menjadi penilaian autentik yaitu mengukur tidak hanya tingkat kognitif atau pengetahuan saja akan tetapi meliputi kompetensi pengetahuan, sikap, dan keterampilan/kecakapan berdasarkan proses dan hasil; c) penilaian sesuai pada level Kompetensi Dasar (KD), Kompetensi Inti (KI) dan Standar Kompetensi Lulusan (SKL); d) mendorong peserta didik untuk memanfaatkan penilaian portofolio sebagai instrumen untuk nengukur aspek kemandirian (Farida, $2017: 6$ )

Penilaian pembelajaran merupakan komponen yang sangat penting karena dengan penilaian pembelajaran bertujuan untuk mengetahui tingkat ketercapaian tujuan pembelajaran. Oleh karena tersebut kemampuan dalam penilaian pembelajaran harus ada dalam seorang guru, salah satunya yaitu seorang pendidik harus memiliki kemampuan untuk mengembangkan instrumen penilaian. Kemampuan guru dalam mengembangkan instrumen penilaian pembelajaran merupakan salah satu indikator dari kompetensi pedagogik yang harus dimiliki oleh seorang guru. Hal ini telah diatur dalam Permendiknas No. 16 Tahun 2007 Tentang Standar Kualifikasi Akademik dan Kompetensi Guru menyebutkan bahwa kompetensi inti dalam kompetensi pedagogik dalam mengadakan penilaian dan evaluasi proses dan hasil belajar seorang guru yaitu ada 7 (tujuh) indikator dari memahami prinsip-prinsip penilaian sampai dengan mengadministrasikan penilaian yang telah diperoleh secara berkesinambungan.

Namun pada kenyataannya kesulitan dalam penilaian pembelajaran masih ditemui oleh guru. Hal ini dapat dibuktikan dengan masih rendahnya kompetensi 
pedagogik yang dimiliki oleh guru hal ini dapat dilihat dari rendahnya hasil UKG (Ujian Kompetensi Guru) yang dilaksanakan secara nasional. Hasil uji kompetensi guru tahun 2019 yang menyatakan bahwa untuk daerah Jawa Tengah khususnya hasil $\mathrm{UKG}$ tersebut antara lain: $\mathrm{SD}=61.88, \mathrm{SMP}=66.14, \mathrm{SMA}=61.91$, untuk kompetensi pedagogik sebesar 57.25 dan kompetensi professional 65.89 dengan rata-rata 63.30. Hal ini menunjukkan hasil yang kurang jika pemerintah menargetkan hasil UKG harus sebesr 70. (https://npd.kemendikbud.go.id diakses pada tanggal 14 Januari $2020: 20.55$ )

Selain itu, berdasarkan penelitian Siswi Dwi Ayuriyanti (2015 : 67) menyebutkan bahwa berdasarkan hasil angket terkait hambatan guru dalam penilaian pembelajaran adalah : 11\% guru mengalami kesulitan dalam perencanaan penilaian keterampilan, $11 \%$ guru jarang melaksanakan penilaian dengan menggunakan teknik diskusi, $17 \%$ guru mengalami kesulitan dalam membuat penilaian sikap peserta didik, selain itu guru mengalami hambatan dalam melakukan penilaian karena banyaknya yang harus dibuat dan banyaknya aspek yang harus dinilai sebesar $19 \%$, dan $42 \%$ mengakui tidak mengalami hambatan dalam mengerjakan penilaian pembelajaran. Hal tersebut membuktikan bahwa masih banyaknya guru yang mengalami kesulitan dalam penilaian keterampilan di sekolah.

Seorang guru harus dapat mengembangkan instrumen penilaian sesuai mata pelajaran yang diampu termasuk untuk mata pelajaran Pendidikan Pancasila dan Kewarganegaraan (PPKn). Menurut Permendiknas No. 22 Tahun 2006, mata pelajaran Pendidikan Pancasila dan Kewarganegaraan (PPKn) merupakan mata pelajaran yang fokus untuk membentuk pemahaman yang baik dari warga sehingga kemudian dapat melaksanakan hak serta kewajibannyaa secara cerdas, terampil, dan berkarakter yang diamanatkan oleh Pancasila dan UUD 1945. (Winarno, $2014: 18$ ).

Tujuan dari mata pelajaran PPKn yaitu untuk menjadikan seseorang menjadi warga negara yang baik (good citizen). Seorang warga negara yang baik harus memiliki 3 (tiga) komponen, antara lain : pengetahuan kewarganegaraan (civic knowledge), keterampilan/kecakapan kewarganegaraan (civic skills), dan karakter kewarganegaraan (civic dispositions). Keterampilan/kecakapan kewarganegaraan merupakan komponen yang penting karena menurut hasil penelitian Ika Murtiningsih \& Kokom Komalasari (2017:87) yang menyebutkan bahwa kecakapan kewarganegaraan (civic skills) menjadi bekal bagi peserta didik sehingga memiliki kemampuan dalam berpengetahuan, ilmiah, efektif, serta bertanggung jawab dan memiliki kemampuan berpikir kritis dan ikut serta dalam kegiatan politik pemerintahan.

Akan tetapi dari hasil observasi awal dan studi dokumen RPP yang digunakan guru dalam mengembangkan instrumen penilaian keterampilan/kecakapan kewarganegaraan peserta didik di SMK Negeri 1 Karanganyar, khususnya guru mata pelajaran PPKn, guru belum mampu mengukur untuk kompetensi kecakapan/keterampilan kewarganegaraan. 
Kecakapan kewarganegaraan terdiri dari sub ranah kecakapan intelektual (intellectual skills) dan sub ranah kecakapan berpartisipsi (partisipatory skills). Menurut Winarno (2014:150) indikator pencapaian kompetensi untuk sub ranah kecakapan intelektual terdiri dari mengidentifikasi, menggambarkan, menjelaskan, menganalisis, menilai dan mengambil dan mempertahankan posisi atas isu Sedangkan untuk sub ranah kecakapan berpartisipasi terdiri dari kecakapan berinteraksi (interacting), memonitor atau memantau (monitoring) dan mempengaruhi (influencing). Apabila kecakapan/keterampilan kewarganegaraan disandingkan dengan pengelompokan Benjamin S Bloom maka sejajar dengan aspek psikomotorik. Akan tetapi, meskipun sejajar, namun tetap perlu dibedakan. Dalam taksonomi bloom aspek psikomotorik adalah bentuk kekuatan otot dan manipulasi fisik. Akan tetapi untuk kecakapan kewarganegaraan lebih kepada keterampilannya dalam ikut serta dalam kegiatan pemerintahan sebagai tanggung jawab kewarganegaraannya. (Winarno, 2014 : 167)

Selain itu orientasi untuk mata pembelajaran PPKn hanya berfokus pada pemahaman akan civic knowledge dan yang akan diajarkan hanya berupa konsepkonsep keilmuan PPKn dan bersifat hafalan semata. Sehingga, orientasi pada pemahaman civic knowledge harus dilanjutkan pada sub ranah cognitive/intellectual skills karena pada dasarnya cognitive/intellectual civic skills tidak dapat dipisahkan dengan civic knowledge (Winarno, 2014 : 166).

Berdasarkan uraian di atas, maka penelitian ini bertujuan untuk mengetahui strategi guru PPKn dalam mengembangkan instrumen penilaian kecakapan kewarganegaraan, serta kendala dan solusi dalam mengembangkan instrumen penilaian kecakapan kewarganegaraan.

\section{METODE}

Tempat penelitian adalah tempat atau sebagai sumber untuk mendapatkan data atau informasi yang dibutuhkan dalam penelitian. Peneliti memilih SMK Negeri 1 Karanganyar sebagai tempat penelitian yang merupakan sekolah kejuruan yang unggul di Karanganyar serta selalu mengikuti perkembangan kurikulum yang berlaku dengan baik. Penelitian ini menggunakan metode kualitatif dengan pendekatan studi kasus. Artinya data yang dikumpulkan menggunakan pendekatan studi kasus yaitu data yang terkumpul saling menyatu untuk mempertegas serta memperjelas suatu objek. Sehingga pendekatan studi kasus ini untuk penelitian deskriptif serta eksploratif (Gunawan, 2017 : 117). Dengan demikian, peneliti menggunakan pendekatan studi kasus, yaitu penelitian ini berusaha mengumpulkan data dan informasi secara mendalam terkait persoalan atau kasus dalam dunia pendidikan khususnya untuk mendeskripsikan strategi guru dalam mengembangkan instrumen penilaian kecakapan kewarganegaraan, kendala guru dalam mengembangkan instrumen penilaian kecakapan kewarganegaraan mata pelajaran PPKn di SMK Negeri 1 Karanganyar serta solusi dalam mengatasi kendala yang dialami guru tersebut. 
Penelitian ini memperoleh sumber data dari informan, tempat serta analisis dokumen. Menurut Lofland dan Loflanf dalam (Lexy J Moleong, 2012 : 157) menyatakan bahwa sumber data pada penelitian kualitatif yaitu dapat berupa tindakan nyata, kata-kata dari subjek selain itu juga berupa data tambahan atau data sekunder meliputi dokumen pendukung untuk memperkuat data primer atau sumber data tersebut. Informan dalam penelitian ini yaitu wakil kepala sekolah bidang kurikulum, guru mata pelajaran PPKn serta peserta didik yang merupakan informan kunci (key informan) yang dapat memberikan informasi terkait penelitian.

Teknik pengumpulan data yang digunakan dalam penelitian ini yaitu wawancara, observasi, dan studi dokumen. Wawancara digunakan untuk mendapatkan informasi maupun data kepada narasumber atau informan secara langsung sehingga data yang didapat lebih jelas serta mendalam. Peneliti melakukan wawancara terhadap guru PPKn, wakil kepala sekolah bidang kurikulum, serta peserta didik untuk memperoleh data primer berdasarkan pedoman wawancara yang telah disusun. Selain itu observasi dilakukan dengan mengamati saat pelaksanaan proses pembelajaran khususnya terkait penilaian kecakapan kewarganegaraan yang dilakukan secara daring melalui google classroom dikarenakan pandemi. Dokumen yang dianalisis dalam penelitian yaitu Rencana Pelaksanaan Pembelajaran (RPP) dan instrumen penilaian untuk mengukur kecakapan kewarganegaraan peserta didik.

Penelitian ini menggunakan uji validitas data berupa tianggulasi sumber dan trianggulasi metode. Penggunaan triangulasi ini dilakukan agar data yang diperoleh dipastikan benar dan bisa saling melengkapi apabila salah satu sumber ataupun metode terdapat kekurangan.

\section{HASIL PENELITIAN DAN PEMBAHASAN}

\section{Strategi Guru PPKn dalam Mengembangkan Instrumen Penilaian Kecakapan Kewarganegaraan}

Menurut Winarno (2014:59) seorang guru PPKn sebelum menyusun instrumen penilaian harus menguasai terkait prinsip-prinsip penilaian dan evaluasi proses dan hasil belajar bidang PKn. Dalam hal ini seorang guru PPKn harus mengerti kompetensi yang harus dimiliki seorang siswa agar tujuan dari PPKn tersebut tercapai dengan baik. Kompetensi yang harus dimiliki yaitu ada 3 (tiga) dan salah satunya yaitu kompetensi kecakapan/keterampilan kewarganegaraan (civic skills). Berikut merupakan strategi yang dilakukan oleh guru PPKn SMK Negeri 1 Karanganyar dalam mengembangkan instrumen penilaian kecakapan kewarganegaraan: 
a. Memperhatikan Karakteristik Siswa Setiap Kelas atau Jurusan/Program Keahlian Terkait Pemahaman Materi dan Tingkat Berpikir Siswa Saat Pembelajaran

SMK Negeri 1 Karanganyar memiliki 6 (enam) jurusan/program keahlian yaitu Akuntasni dan Keuangan Lembaga (AKL), Multimedia, Otomatis dan Tata Kelola Perkantoran (OTKP), Bisnis Daring dan Pemasaran (BDP), Tata Busana dan Usaha Perjalanan Wisata (UPW). Karena memiliki cukup banyak jurusan/program keahlian sehingga karakteristik siswa dari setiap jurusanpun juga berbeda-beda. Karakteristik siswa dan tingkat berpikir siswa dapat dilihat dari catatan guru berupa simbol tertentu atau juga dapat dilihat dari nilai siswa sebelumnya.

Pengembangan kompetensi dasar harus memperhatikan beberapa hal antara lain: karakteristik peserta didik, kemampuan awal, serta karakteristik dari mata pelajaran tersebut, sehingga pemahaman terhadap karakteristik siswa ini dianggap sangat penting. (Alimuddin, 2014 : 28)

Selain itu menurut Asrul dkk (2015: 16) bahwa aspek yang diperlukan dalam penilaian pembelajaran yaitu yang pertama adalah : aspek terkait tingkat berpikir peserta didik yang termasuk di dalamnya yaitu berupa intelegensi, daya ingat, cara meninterpretasi data serta memberikan penjelasan yang masuk akal dan mudah dimengerti.

Maka dari itu penting sekali bagi guru untuk mengetahui karakteristik siswa pada saat pembelajaran, sehingga dengan mengetahui karakteristik siswa maka siswa akan dapat diarahkan ke berpikir kritis, sehingga dalam penilaian keterampilan saat presentasi atau penilaian yang lain untuk menilai kecakapan kewarganegaraan tidak menemui kendala yang berarti.

\section{b. Memperhatikan Kompetensi Dasar (KD) dan Materi yang Akan Dibuat Soal atau Instrumen}

Kompetensi dasar merupakan dasar atau pedoman dalam menyusun instrumen penilaian. Hal ini dapat diartikan bahwa soal atau instrumen yang dibuat harus mampu mengukur ketercapaian Kompetensi Dasar (KD) yang diperinci lagi dalam Indikator Pencapaian Kompetensi (IPK).

Proses memperhatikan Kompetensi Dasar (KD) dan materi merupakan hal yang penting dalam menyusun instrumen penilaian. Hal ini karena Kompetensi Dasar (KD) yang telah ada maka akan dijabarkan lebih ke dalam Indikator Pencapaian Kompetensi (IPK) sehingga dapat diketahui apakah tujuan pembelajaran dapat tercapai atau tidak. Bahkan menurut Mansur (2012: 5-9) menyatakan bahwa memperhatikan Kompetensi Dasar (KD) merupakan langkah yang pertama dalam menyusun perencanaan penilaian yaitu :

1. Menganalisis kompetensi dasar yang akan diturunkan ke dalam indikator;

2. Menetapkan tujuan pembelajaran; 
3. Menyusun skenario pembelajaran yang akan digunakan;

4. Menentukan bentuk dan teknik instrumen penilaian yang sesuai

Penetapan tujuan pembelajaran disusun saat penyusunan Rencana Pelaksanaan Pembelajaran (RPP). Penetapan tujuan tersebut berguna juga untuk menentukan materi yang akan disampaikan dan hal atau informasi yang harus diketahui oleh siswa. Dalam memperhatikan Kompetensi Dasar ini, guru dapat melihat atau membuat pemetaan $\mathrm{KI}$ dan $\mathrm{KD}$, sehingga akan mempermudah dalam penyusunan instrumen penilaian.

\section{c. Menyusun Kisi-Kisi Penilaian}

Adanya kisi-kisi ini menjadi hal yang penting dalam pembuatan instrumen penilaian, termasuk untuk instrumen tes keterampilan. Maka dari itu dalam penyusunan kisi-kisi yang akan dinilai maka penentuan aspek yang diukur menjadi penting, hal ini karena berkaitan dengan KI, KD serta indikator sesuai dengan aspek yang dinilai.

Berdasarkan panduan penilaian oleh Kemendikbud (2017), dalam mengembangkan instrumen penilaian keterampilan terdiri dari: 1) penyusunan kisi-kisi, 2) penyusunan instrumen, 3) penyusunan rubrik penilaian. Selain itu menurut Putra (2013:164-165) menyatakan bahwa langkah-langkah yang dilakukan adalah : 1) menentukan aspek yang diukur, 2) menentukan instrumen penilaian yang sesuai, 3) menentukan penjabaran rinci terkait aspek yang diukur, 4) menentukan format instrumen, 5) mengembangkan kisi-kisi, 6) menulis pernyataan yang sesuai dengan kisikisi, 7) analisis rasional terhadap pernyataan yang telah dirumuskan. Dari dua pendapat tersebut menyatakan bahwa penyusunan kisi-kisi menjadi hal yang harus ada dalam langkah penyusunan instrumen penilaian keterampilan dalam hal ini adalah instrumen non tes.

Akan tetapi berdasarkan telaah terhadap dokumen Rencana Pelaksanaan Pembelajaran (RPP), maka dapat dilihat bahwa tidak ada kisikisi sehingga instrumen penilaian hanya terdiri rubrik penilaian dan pedoman penskoran. Padahal penyusunan kisi-kisi penilaian dimaksudkan agar aspek yang dinilai benar-benar representatif dan relevan dengan materi dan yang seharusnya diukur.

\section{d. Menentukan Teknik dan Bentuk Instrumen Penilaian}

Hal yang tidak boleh lupa dalam penyusunan instrumen penilaian adalah menentukan teknik dan bentuk instrumen penilaian. Karena dengan telah menentukan teknik dan bentuk instrumen penilaian, hal tersebutlah yang menjadi acuan dalam menyusun instrumen penilaian tersebut. Maka dari itu penggunaan dari berbagai teknik penilaian harus sesuai dengan tujuan penilaian, waktu yang tersedia, sifat tugas yang dilakukan siswa, dan materi pembelajaran.

Menurut Subali dalam (Diawati, 2018 : 11) dalam memilih teknik instrumen penilaian harus mempertimbangkan berapa hal sebagai berikut: 
1. Ciri atau karakteristik mata pelajaran;

2. Kompetensi dari mata pelajaran yang ada dalam silabus;

3. Indikator Pencapaian Kompetensi (IPK)

Berdasarkan telaah terhadap dokumen Rencana Pelaksanaan Pembelajaran (RPP) yang di dalamnya memuat instrumen penilaian keterampilan bentuk instrumen yang digunakan guru adalah instrumen nontes yaitu berbentuk lembar pengamatan penilaian kinerja/presentasi/diskusi akan tetapi karena pandemi yaitu pelaksanaannya hanya dengan diskusi melalui aplikasi google classroom.

Kemudian menurut hasil observasi teknik yang dipilih dalam penilaian keterampilan adalah teknik diskusi, sehingga pemilihan teknik dan bentuk penilaian ini menjadi sangat penting karena akan mentukan bagaimana instrumen penilaian tersebut.

\section{e. Mencari Permasalahan/Kasus yang Dapat Dikaitkan dengan Materi Pembelajaran}

Pemilihan permasalahan/kasus harus sesuai dengan teknik penilaian yang telah diambil. Dari hasil observasi menyatakan bahwa guru menggunakan teknik penilaian praktik/kinerja yaitu diskusi di kelas. Pemilihan kasus/permasalahan yang tepat akan mempermudah memahami materi hal itu karena dengan mengetahui permasalahan di dunia nyata maka siswa akan terasah pola pikirnya serta daya berpikir kritis siswa dan tingkat partisipasi siswa menjadi meningkat dalam upaya memecahkan permasalahan tersebut. Hal ini sesuai dengan pendapat Diawati (2018 : 119) yaitu untuk mengetahui yang dinilai itu adalah kompetensi riil dari siswa, maka penilaian yang dilakukan harus dilakukan secara otentik (nyata, riil dalam kehidupan sehari-hari), yaitu salah satu contohnya dihadapkan dengan permasalahan/kasus dalam kehidupan sehari-hari.

Akan tetapi, berdasarkan telaah dokumen Rencana Pelaksanaan Pembelajaran (RPP) dan instrumen penilaian yang digunakan oleh guru terutama untuk aspek keterampilan disana tidak tercantum permasalahan/kasus yang akan menjadi bahan diskusi. Padahal, penyusunan permasalahan/kasus tersebut dimaksudkan agar lebih jelas terkait pelaksanaan penilaian, dan kasus yang dijadikan bahan diskusi benar-benar sesuai dengan materi pembelajaran.

\section{f. Menyusun Soal, Kriteria (Rubrik) Penilaian dan Pedoman Penskoran}

Setelah menentukan persoalan/masalah/kasus yang digunakan, maka langkah selanjutnya yaitu menyusun soal berupa kalimat perintah atau petunjuk pelaksanaan penilaian/penugasan. Kemudian menyusun dan menentukan aspek/kriteria (rubrik) untuk penilaian tersebut. Kriteria ini bersifat luwes sesuai dengan penilaian yang dilakukan.

Selain itu penetapan kriteria atau rubrik akan menghindari dari subjektivitas dari guru (Supardi, 2015 : 185). Selain itu, setelah ditetapkan 
kriteria yang terakhir adalah dibuat pedoman penskoran untuk mengetahui hasil akhir dari kemampuan siswa tersebut.

\section{g. Menelaah Soal Berdasarkan Kaidah Pembuatan Soal dan Kriteria Instrumen Penilaian Psikomotor}

Setelah semua instrumen selesai dibuat, maka langkah selanjutnya yaitu menelaah soal atau instrumen yang sudah dibuat yaitu apakah sudah berdasarkan kaidah pembuatan soal dan kriteria atau belum.

Menurut Burhanudin Tola dan Fahmi dalam Supardi (2015 : 45) menyatakan bahwa dalam menelaah instrumen penilaian khususnya untuk ranah psikomotor adalah dengan melakukan perbandingan serta pemeriksaan kembali dengan aspek penilaian yang digunakan oleh orang lain sebelumnya. Selain itu menurut Arifin (2012 : 101) mengatakan bahwa dengan menelaah soal/instrumen tersebut maka kesalahan dapat langsung diperbaiki oleh guru tersebut.

\section{Kendala dan Solusi dalam Mengembangkan Instrumen Penilaian Kecakapan Kewarganegaraan}

Kendala yang ditemui oleh guru dalam mengembangkan instrumen penilaian kecakapan kewarganegaraan yaitu:

a. Kesulitan Guru dalam Menentukan Permasalahan/Kasus yang Dikaitkan dengan Materi Untuk Bahan Diskusi atau Presentasi

Kendala guru dalam menentukan permasalahan/kasus yang sesuai dengan materi ini terlihat jelas dari hasil observasi bahwa yang dijadikan bahan diskusi hanya terkait permasalahan sederhana dan bersifat umum. Dengan demikian maka seorang guru harus memiliki kompetensi untuk mengadakan penilaian dari tahap perencanaan, pelaksanaan sampai pada tahap evaluasi hal ini merupakan kompetensi yang harus dimiliki oleh seorang guru yaitu kompetensi pedagogik.

\section{b. Karakteristik Siswa Masih Kurang Dalam Keaktifan dan Penguasaan Materi Pembelajaran \\ Penilaian kecakapan kewarganegaraan sangat membutuhkan} keaktifan siswa agar membantu proses penilaian. Penilaian kecakapan tidak dapat berjalan dengan lancar tanpa keaktifan siswa dan penguasaan materi pembelajaran siswa. Saat guru sudah berusaha mengembangkan instrumen penilaian kecakapan kewarganegaraan dengan baik, akan tetapi dalam pelaksanaannya tidak ada antusias atau bahkan keaktifan siswa yang kurang maka akan berpengaruh terhadap baiknya instrumen tersebut. Maka dari itu, keikutsertaan siswa menjadi penting dalam proses pembelajaran yaitu apabila patokan yang digunakan bisa dipraktikkan kepada semua siswa. (Wulan\&Rusdiana, 2014:59) 
Sesuai dengan hasil observasi bahwa hanya $25 \%$ anak yang ikut serta menyampaikan argumen atau pendapatnya. Hal ini akan berpengaruh terhadap penilaian kecakapan kewarganegaraan yang di dalamnya juga terdapat aspek partisipasi, jika tidak adanya partisipasi maka guru akan merasa kebingungan dalam penilaiannya nanti akan seperti apa.

\section{c. Kesulitan Guru dalam Menentukan Aspek Penilaian Keterampilan Siswa Saat Pembelajaran Jarak Jauh (PJJ)}

Keadaan yang terjadi ke depannya memang tidak bisa kita prediksi sebelumnya, termasuk sekarang yaitu keadaan pandemi yang menuntut untuk melaksanakan pembelajaran secara daring termasuk dalam penilaian. Hal ini berpengaruh dalam keberjalanan penilaian tersebut, instrumen yang sudah disusun sebelumnya dan dipersiapkan dengan baik akan tetapi karena pandemi instrumen yang telah disusun tidak dapat untuk dimplementasikan dalam pembelajaran secara online. Hal ini sesuai dengan pernyataan informan guru 3 yang menyatakan bahwa "Untuk kendalanya dalam menyusunnya mungkin tidak ada ya mbak hanya saja saat pandemi ini penilaian keterampilan menjadi sulit untuk dinilai jadi saya juga bingung aspek yang dinilai seperti apa, jadi saat pandemi ini penilaian sikap dan keterampilan dikesampingkan terlebih dahulu." (Kutipan wawancara 3, tanggal 10 Agustus 2020).

Maka dari itu seorang guru harus dapat menyesuaikan keadaan yang sedang terjadi termasuk penyesuaian dalam pengembangan instrumen penilaian khususnya untuk penilaian keterampilan/kecakapan kewarganegaraan karena keterampilan/kecakapan kewarganegaraan menjadi sulit untuk dinilai pada saat Pembelajaran Jarak Jauh (PJJ).

Dari permasalahan/kendala yang temui guru di lapangan, maka guru dan pihak yang terkait berusaha untuk mencari solusi agar kegiatan penilaian kecakapan kewarganegaraan tetap berjalan dengan baik. Solusi dari kendala dalam mengembangkan instrumen penilaian kecakapan kewarganegaraan antara lain:

\section{a. Mengikuti Berita yang Terjadi Di Masyarakat Serta Kreatif Dalam Mengaitkan dengan Materi}

Kendala yang dialami guru PPKn tersebut dalam menentukan permasalahan/kasus dapat disebabkan karena guru PPKn kurang mengikuti berita yang ada di masyarakat. Jika guru PPKn tersebut berusaha untuk selalu mengikuti berita maka dengan sendirinya akan muncul ide kreatif kepada guru untuk dapat mengaitkan berita yang ditemui dengan materi pembelajaran. Maka dari itu seorang guru harus selalu mengikuti berita yang ada. Hal ini dikarenakan dengan tema diskusi ataupun berita yang yang diambil dari contoh nyata dalam kehidupan sehari-hari maka akan meningkatkan minat belajar siswa dan siswa juga akan terpancing untuk aktif dalam diskusi pembelajaran. 
CIVICS EDUCATION AND SOCIAL SCIENSE JOURNAL(CESSJ)

Volume 3 Nomor 1 Edisi Bulan Juni 2021

\section{b. Memberikan Motivasi dan Ajakan Secara Terus Menerus kepada Siswa}

Mengatasi siswa yang pasif bukan perkara yang mudah, maka diperlukan peran dari semua pihak terutama dari guru. Seorang guru merupakan dalang di kelas saat pembelajaran berlangsung. Saat penilaian pembelajaran guru berperan juga dalam memantau yaitu memberikan bantuan serta umpan balik kepada setiap siswa, bantuan tersebut berupa dorongan agar siswa mengikuti kegiatan belajar-mengajar dengan baik (Wulan\&Rusdiana, 2014: 58).

Penilaian di sekolah seharusnya mendorong siswa untuk belajar, hal ini sejalan dengan pendapat Djemari (2012: 14) yaitu sistem penialaian yang digunakan disetiap satuan pendidikan harus mampu:

1. Memberi informasi yang tepat

2. Mendorong peserta didik untuk belajar

3. Memotivasi guru agar dapat mengajar dengan baik

4. Memperbaiki kinerja lembaga

5. Meningkatkan mutu pendidikan

c. Pengadaan Workshop Terkait Peningkatan Profesionalitas Guru dalam Pembelajaran Jarak Jauh (PJJ)

Guru tetap berusaha agar penilaian kecakapan/keterampilan siswa ini agar tetap dapat dilaksanakan dan mengukur keterampilan siswa salah satunya yaitu guru menghilangkan salah satu aspek yang tidak dapat diukur saat Pembelajaran Jarak Jauh (PJJ). Hal ini dapat dilihat dari instrumen penilaian yang digunakan guru bahwa aspek "kerjasama kelompok" tidak dinilai oleh guru tersebut. Selain solusi dari guru, sekolah melalui kurikulum pun juga ikut andil dalam mengatasi kendala atau permasalahan yang dialami guru dalam mengembangkan instrumen penilaian kecakapan kewarganegaraan terutama saat pandemi seperti ini. Sekolah melalui kurikulum telah memberikan fasilitas workshop terkait pembelajaran jarak jauh yang dilaksanakan selama 2 (dua) hari yang berisi terkait pelatihan untuk guru-guru dalam menggunakan aplikasi-aplikasi pada saat pembelajaran jarak jauh, sehingga walaupun saat pandemi kegiatan belajar mengajar harus tetap berjalan dengan baik.

Jika dalam waktu biasanya, kurikulum juga telah memberikan workshop terkait penyusunan silabus maupun RPP yang dilaksanakan setiap awal tahun pelajaran. Sehingga pengadaan workshop disini dapat kita lihat juga menyesuaikan keadaan atau kondisi yang sedang terjadi.

Berdasarkan uraian di atas dapat kita ketahui bahwa panduan penilaian oleh Kemendikbud (2017), dalam mengembangkan instrumen penilaian keterampilan terdiri dari: 1) penyusunan kisi-kisi, 2) penyusunan instrumen, 3) penyusunan rubrik penilaian. Selain itu menurut Putra (2013:164-165) menyatakan bahwa langkah-langkah yang dilakukan adalah : 1) menentukan aspek yang diukur, 2) 
menentukan instrumen penilaian yang sesuai, 3) menentukan penjabaran rinci terkait aspek yang diukur, 4) menentukan format instrumen, 5) mengembangkan kisi-kisi, 6) menulis pernyataan yang sesuai dengan kisi-kisi, 7) analisis rasional terhadap pernyataan yang telah dirumuskan. Dari dua pendapat tersebut menyatakan bahwa penyusunan kisi-kisi menjadi hal yang harus ada dalam langkah penyusunan instrumen penilaian keterampilan dalam hal ini adalah instrumen non tes.

Kemudian, kita ketahui bahwa langkah-langkah yang dilakukan oleh guru dalam mengembangkan instrumen penilaian kecakapan kewarganegaraan hampir sama dengan langkah-langkah dalam penilaian pengetahuan berorientasi HOTS yang merupakan hasil penelitian dari Fauzan (2019:5-7) hanya saja tetap terdapat perbedaan di dalamnya. Hal ini dikarenakan menurut Penelitian Dewi wulandari (2017: 73) menyebutkan bahwa keterampilan/kecakapan kewarganegaraan bila disandingkan dengan Taksonomi Bloom yaitu untuk intellectual skills dapat disandingkan dengan ranah kognitif untuk tingkatan C4-C6 (HOTS), sedangkan untuk partisipatory skills dapat disandingkan dengan ranah psikomotor. Karena itu intellectual skills dibangun dari civic knowledge, karena intellectual skills dalam rumusan kerjanya merujuk pada pemahaman dan penguasaan materi, hal ini dapat dibuktikan dengan tingkat berpikir kritis peserta didik saat diskusi atau presentasi kelompok. Dapat disimpulkan bahwa antara intellectual skills dan civic knowledge dengan civic skills tidak dapat dipisahkan (inseparable) (Winarno, 2014:163). Selain itu dalam penilaian PPKn diperoleh dari pemahaman konsep nilai yang diperoleh dan kemampuan peserta didik dalam mempraktikkan konsep dari nilainilai kehidupan berbangsa dan bernegara, dalam hal ini adalah dapat dilihat dari penilaian kecakapan kewarganegaraan peserta didik

\section{SIMPULAN}

\section{SIMPULAN}

Berdasar temuan dan pembahasan yang telah dilakukan, maka dapat ditarik kesimpulan sebagai berikut:

1. Strategi guru PPKn dalam mengembangkan instrumen penilaian kecakapan kewarganegaraan di SMK Negeri 1 Karanganyar, yaitu:

a. Memperhatikan karakteristik siswa setiap kelas atau jurusan/program keahlian terkait pemahaman materi dan tingkat berpikir siswa saat pembelajaran

b. Memperhatikan Kompetensi Dasar (KD) dan materi yang akan dibuat soal atau instrumen

c. Menyusun kisi-kisi penilaian

d. Menentukan teknik dan bentuk instrumen penilaian

e. Mencari permasalahan/kasus yang dapat dikaitkan dengan materi pembelajaran

f. Menyusun soal, kriteria (rubrik) penilaian dan pedoman penskoran 
CIVICS EDUCATION AND SOCIAL SCIENSE JOURNAL(CESSJ)

Volume 3 Nomor 1 Edisi Bulan Juni 2021

g. Menelaah soal berdasarkan kaidah pembuatan soal dan kriteria instrumen penilaian psikomotor

2. Kendala dan solusi dalam mengembangkan instrumen penilaian kecakapan kewarganegaraan di SMK Negeri 1 Karanganyar yaitu sebagai berikut:

a. Kesulitan guru dalam menentukan permasalahan/kasus yang dikaitkan dengan materi untuk menjadi bahan diskusi atau presentasi

b. Karakteristik siswa masih kurang dalam keaktifan dan penguasaan materi pembelajaran

c. Kesulitan guru dalam menentukan aspek penilaian keterampilan siswa saat Pembelajaran Jarak Jauh (PJJ)

Selanjutnya, solusi dari kendala dalam mengembangkan instrumen penilaian kecakapan kewarganegaraan di SMK Negeri 1 Karanganyar yaitu:

a. Mengikuti berita yang terjadi di masyarakat serta kreatif dalam mengaitkan dengan materi

b. Memberikan motivasi dan ajakan secara terus menerus kepada siswa

c. Pengadaan workshop terkait Peningkatan Profesionalitas Guru dalam Pembelajaran Jarak Jauh (PJJ)

\section{SARAN}

Berdasarkan simpulan dari penelitian ini, adapun saran yang diberikan yaitu sebagai berikut:

1. Bagi Peserta Didik

a. Siswa perlu meningkatkan kemampuan berpikir kritis dalam pembelajaran berlangsung seperti saat diskusi ataupun dalam menemui permasalahan dalam masyarakat

b. Siswa perlu meningkatkan pemahaman terhadap materi sehingga dapat mengikuti dan ikut aktif dalam pembelajaran

c. Siswa perlu meningkatkan keikutsertaan dan keaktifan baik dalam kelas ataupun dalam partisipasi kegiatan di sekolah, bermasyarakat, ataupun bernegara.

2. Bagi Guu

a. Guru perlu mengikuti berita di masyarakat dan kreatif untuk mengaitkan dengan materi pembelajaran

b. Guru perlu membiasakan pembelajaran yang menuntut tingkat berpikir kritis dan partisipasi siswa

3. Bagi Sekolah

Sebaiknya sekolah mengadakan workshop terkait penyusunan instrumen penilaian yang dapat dilaksanakan saat pandemi covid, sehingga pembelajaran dan penilaian masih tetap bisa dilaksanakan walapun saat pandemi. 
CIVICS EDUCATION AND SOCIAL SCIENSE JOURNAL(CESSJ)

Volume 3 Nomor 1 Edisi Bulan Juni 2021

\section{REFERENSI}

Arifin, Z. (2012). Penelitian Pendidikan. Bandung: PT. Remaja Rosdakarya

Asrul dkk. (2015). Evaluasi Pembelajaran. Bandung : Citapustaka Media

Djemari. (2012). Pengukuran Penilaian Evaluasi Pendidikan. Yogyakarta: Nuha Medika.

Diawati, C (2018). Dasar-Dasar Perancangan dan Evaluasi Pembelajaran. Yogyakarta: Graha Ilmu

Farida, I. (2017). Evaluasi Pembelajaran Berdasarkan Kurikulum Nasional. Bandung : PT Remaja Rosdakarya Offset

Gunawan, I. (2017). Metode Penelitian Kualitatif Teori dan Praktik. Jakarta : Bumi Aksara

Kementerian Pendidikan dan Kebudayaan. (2017). Panduan Penilaian Oleh Pendidik dan Satuan Pendidikan Sekolah Menengah Pertama. Jakarta: Direktorat Jenderal Guru dan Tenaga Kependidikan

Mansur. (2012). Media Pendidikan LPMP Sulawesi Selatan. Implementasi Penilaian Autentik Kurikulum 2013 di Sekolah Menengah Atas (SMA), 4-21

Moleong, L. J. (2012). Metodologi Penelitian Kualitatif. Bandung : PT. Remaja Rosdakarya

Putra, S. R. (2013). Desain Evaluasi Belajar Berbasis Kinerja. Jogjakarta : Diva Press

Supardi (2015). Penilaian Autentik: Pembelajaran Afektif, Kognitif, dan Psikomotor (Konsep dan Aplikasi). Jakarta: Rajawali Press

Winarno. (2014). Pembelajaran Pendidikan Kewarganegaraan : Isi, Strategi, dan Penilaian. Jakarta : PT. Bumi Aksara

Wulan, E.R\&Rusdiana. (2014). Evaluasi Pembelajaran. Bandung: Pustaka Setia

Jurnal dan Skripsi:

Alimuddin. (2014). Penilaian Dalam Kurikulum 2013. Jurnal Prosiding Seminar Nasional Pendidikan Karakter. Vol 01. No (1). UNM Makassar

Ayuriyanti, S.D. (2015). Hambatan Guru Dalam Perencanaan, Pelaksanaan dan Penilaian Pembelajaran Kompetensi Keahlian Multimedia Pada Penerapan Kurikulum 2013 Di SMK Se Daerah Istimewa Yogyakarta. Skripsi. Universitas Negeri Yogyakarta

Fauzan, A. N (2019). Strategi Guru PPKn Dalam Mengembangkan Instrumen Penilaian Pengetahuan Berorientasi Higher Order Thinking Skills (Studi di 
CIVICS EDUCATION AND SOCIAL SCIENSE JOURNAL(CESSJ)

Volume 3 Nomor 1 Edisi Bulan Juni 2021

SMA Negeri 1 Surakarta). Jurnal Prosiding Seminar Nasional Pendidikan Kewarganegaraan 2019. Universitas Sebelas Maret Surakarta

Murtiningsih. I \& Komalasari. K. 2017. Model Group Investigation Untuk Meningkatkan Kecakapan Kewarganegaraan. Jurnal Ilmu Pendidikan. Pendidikan Kewarganegaraan Sekolah Pascasarjana UPI Bandung.

Wulandari, Dewi. (2017). Analisis Penilaian Keterampilan Kewarganegaraan Siswa kelas X IPS Mata Pelajaran Pendidikan Pancasila dan Kewarganegaraan (PPKn) di SMA Negeri 1 Sukoharjo Pada Semesrter II Tahun Pelajaran 2016/2017. Skripsi. Universitas Sebelas Maret

Peraturan Kementerian Pendidikan dan Kebudayaan Nomor 23 Tahun 2016 tentang Standar Penilaian

Peraturan Kementerian Pendidikan Nasional Nomor 16 Tahun 2007 Tentang Standar Kualifikasi Akademik dan Kompetensi Guru

Peraturan Pemerintah Nomor 19 Tahun 2005 Tentang Standar Nasional Pendidikan

Undang-Undang Nomor 20 Tahun 2003 Tentang Sistem Pendidikan Nasional 